\title{
PENGARUH EKSTRAK KUNYIT, KENCUR, JAHE, DAN LENGKUAS TERHADAP PENYAKIT BULAI PADA TANAMAN JAGUNG MANIS (Zea mays saccharata)
}

\author{
Devita Alfandri, Joko Prasetyo \& Tri Maryono \\ Jurusan Agroteknologi, Fakultas Pertanian Universitas Lampung \\ Jl. Prof. Soemantri Brodjonegoro, No. 1, Bandar Lampung 35145 \\ E-mail: Devitaalfandri@gmail.com
}

\begin{abstract}
ABSTRAK
Salah satu penyakit penting dalam budidaya jagung manis adalah penyakit bulai yang disebabkan oleh jamur Peronosclerospora maydis. Penelitian bertujuan untuk mengetahui pengaruh ekstrak rimpang (kunyit, kencur, jahe, dan lengkuas) untuk mengendalikan penyakit bulai (P. maydis) pada tanaman jagung manis. Penelittian dilaksanakan dari Mei-Agustus 2012 di Laboratorium Penyakit Tanaman, Fakultas Pertanian, Universitas Lampung. Perlakuan dalam percobaan ini disusun dalam Rancangan Acak Lengkap (RAL) dengan lima ulangan. Perlakuan terdiri atas kontrol berupa air steril (P0), ekstrak kunyit (P1), ekstrak kencur (P2), ekstrak jahe (P3), ekstrak lengkuas (P4), dan fungisida sintetik (dimetomorf 0,5 g/l) sebagai pembanding (P5). Peubah yang diamati adalah keterjadian penyakit, masa inkubasi, tinggi, bobot kering dan basah tanaman. Pengamatan dilakukan setiap hari selama tiga minggu. Data hasil pengamatan kemudian dianalisis dengan sidik ragam. Hasil penelitian menunjukan ekstrak kunyit, kencur, jahe, dan lengkuas tidak efektif dalam menekan keterjadian penyakit bulai pada jagung manis.
\end{abstract}

Kata kunci: Penyakit bulai, ekstrak rimpang, Peronosclerospora maydis

\section{PENDAHULUAN}

Jagung manis merupakan komoditas pertanian yang sangat digemari, karena mengandung kadar gula yang relatif tinggi sehingga rasanya manis. Selain itu jagung manis juga banyak mengandung karbohidrat dan sedikit lemak. Ciri dari jenis ini adalah bila masak bijinya menjadi keriput. Jagung manis dapat dimanfaatkan sebagai bahan makanan, pakan ternak, bahan baku pengisi obat, dan lain-lain (Harizamrry, 2007). Budidaya jagung manis berpeluang memberikan untung yang tinggi, namun sifat ketahanan jagung manis yang rendah terhadap hama dan penyakit tumbuhan merupakan permasalahan utama dalam budidaya jagung manis (Sudarsana, 2000).

Salah satu penyakit penting dalam budidaya jagung manis adalah penyakit bulai (downy mildew). Penyakit ini disebabkan oleh Peronosclerospora maydis. Kehilangan hasil yang disebabkan oleh penyakit bulai dapat mencapai $60 \%$ bahkan dapat menyebabkan puso (Anonim, 2012). Di Lampung, Luas serangan penyakit bulai pada tahun 2010 menurut BPTPH adalah 599 hektar dan pada tahun 2011 luas serangan meningkat menjadi 1.138 hektar yang mencakup wilayah Lampung Tengah, Lampung Selatan, Lampung Timur, Pesawaran, dan Tanggamus (BPTPH, 2012). Sampai saat ini pengendalian penyakit bulai dilakukan dengan cara perlakuan benih menggunakan fungisida sintetik. Akan tetapi penggunaan fungisida sintetik yang berlebihan justru menimbulkan permasalahan baru seperti, resistensi patogen, pencemaran lingkungan, dan residu pada tanaman yang berbahaya untuk kesehatan (Djojosumarto, 2004). Oleh karena itu, diperlukan pengendalian alternatif yang efektif tetapi juga ramah lingkungan.

Salah satu alternatif pengendalian tersebut adalah penggunaan fungisida nabati. Fungisida nabati adalah fungisida yang bahan dasarnya berasal dari tanaman atau tumbuhan. Tanaman yang dapat digunakan sebagai fungisida nabati antara lain kunyit, kencur, jahe, dan lengkuas. Tumbuhan tersebut mengandung senyawa seperti minyak atsiri, sineol, dan alkaloid, yang diduga dapat berperan sebagai fungisida nabati (Paramitasari, 2011). Dari uraian tersebut maka perlu dilakukan penelitian tentang efektivitas ekstrak kunyit, kencur, jahe, dan lengkuas sebagai fungisida nabati untuk mengendalikan penyakit bulai pada tanaman jagung. Penelitian ini bertujuan untuk mengetahui efektivitas ekstrak rimpang kunyit, kencur, jahe, dan lengkuas dalam mengendalikan penyakit bulai pada tanaman jagung manis.

\section{BAHAN DAN METODE}

Penelitian ini dilaksanakan dari bulan Mei Agustus 2012 di Laboratorium Penyakit Tanaman 
Jurusan Proteksi Tanaman Fakultas Pertanian Universitas Lampung. Bahan yang digunakan dalam penelitian ini adalah benih jagung manis varietas jambore politeknik, ekstrak kunyit, ekstrak kencur, ekstrak jahe, dan ekstrak lengkuas, suspensi spora $P$. maydis, pupuk kandang, fungisida sintetik (dimetomorf $0,5 \mathrm{~g} \mathrm{l}^{-1}$ ), dan aquades. Sedangkan alat-alat yang digunakan adalah botol kaca, tissu, tabung reaksi, gelas ukur, rak gelas ukur, rotary mixer, mikroskop stereo, pipet tetes, autoklaf, bunsen, blender, plastik tahan panas, kertas koran, cangkul, dan polibag.

Penelitian ini dilaksanakan dalam Rancangan Acak Lengkap terdiri dari 6 perlakuan dan 5 ulangan. Setiap unit percobaan terdiri atas 6 tanaman jagung. Perlakuan terdiri atas air steril sebagai kontrol (P0), ekstrak kunyit (P1), ekstrak kencur (P2), ekstrak jahe (P3), ekstrak lengkuas (P4), dan fungisida sintetik (dimetomorf $0,5 \mathrm{~g} \mathrm{l}^{-1}$ ) (P5). Data yang diperoleh dianalisis dengan analisis sidik ragam(ANOVA) dan dilanjutkan dengan Uji Beda Nyata Terkecil (BNT) pada taraf $5 \%$.

Benih yang digunakan adalah benih jagung manis varietas jambore politeknik. Benih ditanam pada polibag berisi tanah yang telah diberi pupuk kandang $(2: 1)$ dengan jumlah biji yang ditanam adalah 6 biji per polibag. Pupuk kandang yang digunakan dalam penelitian ini berasal dari kotoran kambing. Polibag diletakkan di lahan Laboratorium Jurusan Proteksi Tanaman, Fakultas Pertanian, Universitas Lampung.Setelah berumur 6 hari, bibit jagung manis siap diaplikasikan dengan fungisida nabati. Pemeliharaan berupa penyiraman dan pembersihan gulma dilakukan sesuai kebutuhan.

Fungisida nabati yang digunakan dalam penelitian ini adalah kunyit, kencur, jahe, dan lengkuas. Masingmasing jenis rimpang ditimbang sebanyak 500 gram dicuci bersih dan dipotong kecil-kecil kemudian dioven pada suhu $50^{\circ} \mathrm{C}$ selama 5 hari. Setelah dioven, masingmasing jenis rimpang ditimbang sebanyak 50 gram dan diblender sehingga diperoleh tepung yang halus. Tepung yang didapat tersebut kemudian disimpan sampai digunakan.

Tepung rimpang yang halus kemudian digunakan untuk membuat larutan induk (aliquot) ekstrak rimpang. Larutan induk ekstrak rimpang dibuat dengan cara mencampurkan tepung rimpang sebanyak 30 gram dengan $70 \mathrm{ml}$ air steril. Larutan induk tersebut kemudian diendapkan selama 1 jam. Setelah 1 jam, 3 ml larutan induk diambil dan diencerkan dengan $5 \mathrm{ml}$ air steril. Kemudian hasil pengenceran ini dicampur dengan $2 \mathrm{ml}$ suspensi spora dan disimpan selama 1 jam. Setelah 1 jam campuran ekstrak rimpang dengan suspensi spora tersebut digunakan dalam inokulasi buatan.
Spora yang digunakan merupakan spora yang berasal dari tanaman sakit yang diambil dari lahan pertanaman jagung Politeknik Negeri Lampung. Spora dipanen dengan cara permukaan daun jagung yang terserang penyakit bulai ditekuk dan diberi air. Permukaan daun yang berisi air tersebut dikeruk menggunakan spatula sehingga didapatkan suspensi spora. Setelah itu suspensi spora diambil menggunakan pipet tetes dan disimpan dalam botol kaca. Suspensi yang telah didapat kemudian dihomogenkan menggunakan rotary mixer.

Sebelum dilakukan inokulasi, terlebih dahulu suspensi spora $P$. maydissebanyak $3 \mathrm{ml}$ dicampur dengan larutan fungisida nabati dan air steril sebanyak $7 \mathrm{ml}$ dan disimpan selama 1 jam. Inokulasi spora $P$. maydisdilakukan pada pukul $03.00-04.00 \mathrm{WIB}$ ketika daun terkena embun. Air embun yang terdapat pada titik tumbuh tanaman diambil dengan pipet tetes kemudian pada titik tumbuh tersebut diinokulasi dengan campuran suspensi spora $P$. maydis dengan fungisida nabati sebanyak $3 \mathrm{ml}$.

Pengamatan dilakukan setiap hari, dimulai 1 hari setelah aplikasi spora $P$. maydis. Peubah yang diamati dalam percobaan ini adalah masa inkubasi, keterjadian penyakit, tinggi tanaman, bobot basah tanaman, dan bobot kering tanaman. Masa inkubasi diamati dari saat inokulasi sampai timbulnya gejala yang pertama. Keterjadian penyakit diamati setiap hari dengan menghitung tanaman yang menunjukan gejala bulai, keterjadian penyakit dihitung dengan rumus :

$$
K p=\frac{n}{N} \times 100 \%
$$

Kp adalah keterjadian penyakit, $\mathrm{n}$ adalah jumlah tanaman terserang, dan $\mathrm{N}$ adalah jumlah tanaman seluruhnya. Tinggi tanaman diukur pada saat $21 \mathrm{hsi}$ dari permukaan tanah sampai daun yang paling tinggi. Bobot basah tanaman diamati pada akhir percobaan yaitu tanaman jagung dicabut hingga ke akar kemudian ditimbang. Bobot kering tanaman diamati setelah tanaman jagung dicabut kemudian tanaman tersebut dijemur dan dioven pada $70^{\circ} \mathrm{C}$ selama 3 hari kemudian ditimbang.

\section{HASIL DAN PEMBAHASAN}

Gejala penyakit bulai pada penelitian ini mulai terlihat pada hari ke 7 setelah inokulasi. Gejala awal bulai ditandai dengan adanya garis-garis klorosis. Gejala ini berkembang dimulai dari pangkal daun kearah ujung 
daun dan menjadi jalur yang sejajar dengan tulang daun. Pada tahap ini biasanya pada permukaan bawah daun jagung terdapat lapisan berwarna putih seperti tepung yang merupakan kumpulan spora $P$. maydis. Gejala sistemik terjadi apabila infeksi patogen mencapai titik tumbuh, sehingga semua daun baru akan mengalami klorosis, dan akhirnya tanaman menjadi kerdil.

Hasil pengamatan menunjukan bahwa keterjadian penyakit bulai terus meningkat disetiap pengamatan. Hasil analisis ragam data keterjadian penyakit bulai menunjukan bahwa aplikasi ekstrak rimpang tanaman tidak berpengaruh nyata terhadap keterjadian penyakit bulai sampai 21 hsi. Perkembangan penyakit bulai terlihat meningkat seiring berrtambahnya waktu. Pada akhir pengamatan, perlakuan yang perkembangan penyakitnya paling rendah adalah fungisida sintetik dimetomorf $0,5 \mathrm{~g} \mathrm{l}^{-1}$ yaitu $60 \%$. Ekstrak rimpang kunyit merupakan ekstrak rimpang tanaman tanaman yang paling rendah perkembangan penyakitnya yaitu $66 \%$.

Hasil analisis ragam data tinggi tanaman, bobot kering tanaman, dan bobot basah tanaman menunjukan bahwa aplikasi ekstrak rimpang (kunyit, kencur, jahe, lengkuas), fungisida sintetik, dan kontrol tidak berpengaruh nyata terhadap tinggi, bobot kering, dan bobot basah tanaman jagung manis.

Hasil penelitian menunjukan bahwa aplikasi ekstrak rimpang (kunyit, kencur, jahe, dan lengkuas) tidak efektif mengendalikan penyakit bulai pada tanaman jagung manis. Pada penelitian ini spora $P$. maydis dicampur terlebih dahulu dalam suspensi fungisida nabati. Hal ini dilakukan dengan harapan setelah terjadi kontak dengan fungisida nabati, spora $P$. maydis akan mati (rusak) sehingga tidak mampu berkecambah, sehingga infeksi tidak terjadi. Namun meskipun sudah di ekspose dalam larutan fungisida nabati, spora $P$. maydis tetap berkecambah dan menginfeksi tanaman sehingga gejala bulai tetap muncul. Diduga hal ini terjadi dikarenakan kurang banyaknya kandungan bahan aktif yang terdapat pada ekstrak kunyit, kencur, jahe, dan lengkuas sehingga tidak cukup untuk menekan perkembangan P.maydis pada tanaman jagung manis.

Selain itu diduga ekstrak kunyit, kencur, jahe, dan lengkuas tidak efektif dalam mengendalikan penyakit bulai pada tanaman jagung manis karena kurang lamanya waktu pencampuran suspensi spora $P$. maydis dalam ekstrak kunyit, kencur, jahe, dan lengkuas. Pada penelitian ini lamanya waktu pencampuran $P$. maydis dengan ekstrak kunyit, kencur, jahe, dan lengkuas hanya dilakukan selama 1 jam.

Penyebab lain yang diduga menyebabkan ekstrak kunyit, kencur, jahe, dan lengkuas tidak efektif dalam mengendalikan penyakit bulai pada tanaman jagung manis adalah frekuensi pengaplikasian fungisida nabati. pada penelitian ini aplikasi fungisida nabati hanya dilakukan setiap minggu selama 21 hari dengan cara diteteskan pada titik tumbuh. Hal ini berbeda dengan Sekarsari (2012) yang melaporkan bahwa ekstrak daun tapak liman , mimba, sirih, dan seraiwangi efektif menekan keterjadian penyakit bulai pada tanaman jagung manis. Pada penelitian tersebut fungisida nabati di aplikasikan tidak hanya pada titik tumbuh, tetapi juga dengan penyemprotan secara merata pada seluruh bagian tanaman dengan interval 3 hari sekali.

Pada penelitian ini juga digunakan fungisida sintetik (dimetomorf $0,5 \mathrm{~g} \mathrm{l}^{-1}$ ) sebagai pembanding. Hasil penelitian menunjukan bahwa fungisida sintetik juga tidak efektif menekan perkembangan penyakit bulai pada jagung manis. Hasil ini berbeda dengan yang dilaporkan Sekarsari (2012) yang melaporkan bahwa fungisida sintetik (dimetomorf $0,5 \mathrm{~g} \mathrm{l}^{-1}$ ) efektif menekan perkembangan penyakit bulai pada jagung manis.

\section{KESIMPULAN}

Kesimpulan yang diperoleh berdasarkan penelitian ini, yaitu ekstrak rimpang kunyit, kencur, jahe, dan lengkuas tidak efektif dalam menekan keterjadian penyakit bulai pada jagung manis.

\section{DAFTAR PUSTAKA}

Anonim. 2012. Hasil pencarian komoditi. Tersedia dalam http://www.deptan.go.id/index1.php. Diakses tanggal 27 maret 2012

Balai Proteksi Tanaman pangan dan hortikultura (BPTPH). 2012. Laporan UPTD Balai Proteksi Tanaman Pangan dan Hortikultura. Provinsi Lampung.

Djojosumarto, P. 2008. Pestisida dan aplikasinya. AgroMedia Pustaka : Jakarta.

Harizamrry. 2007. Artikel jagung manis. Diakses di http://harizamrry.com/2007/.../Tanaman-JagungManis-Sweet-Corn, Tanggal 2 Desember 2012.

Paramitasari, D. 2011. Budidaya rimpang jahe kunyit kencur temulawak. Yogyakarta. $86 \mathrm{hlm}$.

Sekarsari, R. A. 2012. Pengaruh beberapa ekstrak daun terhadap penyakit bulai pada tanaman jagung manis (Zea mays saccharata). Skripsi. Universitas Lampung, Bandar Lampung.

Sudarmo, S. 2009. Pestisida nabati. Kanisius : Yogyakarta. $58 \mathrm{hlm}$. 
Sudarsana, N. K. 2000. Pengaruh efektifitas microorganisme-4 (EM-4) dan kompos terhadap produksi jagung manis (Zea mays saccharata Sturt) pada tanah entisol. Diakses di : http:// www. unmul.ac.id/dat/pub/frontir/ sudarsana.pdf. pada tanggal 20 November 2012. 